\title{
Characterization of a cold-active bacteriophage on two psychrophilic marine hosts
}

\author{
Llyd E. Wells ${ }^{1,2, *}$, Jody W. Deming ${ }^{1}$ \\ ${ }^{1}$ School of Oceanography, University of Washington, Box 357940, Seattle, Washington 98195-7940, USA \\ ${ }^{2}$ Present address: Center for Northern Studies, Sterling College, PO Box 72, Craftsbury Common, Vermont 05827, USA
}

\begin{abstract}
A cold-active bacteriophage designated 9A was isolated against Colwellia psychrerythraea Strain $34 \mathrm{H}$ at near in situ temperature $\left(-1^{\circ} \mathrm{C}\right)$ by enrichment of seawater from an Arctic nepheloid layer, using a newly developed isothermal overlay technique. Phage 9A is classified as a Siphoviridae with a genome size of 80 to $90 \mathrm{~kb}$. In addition to $34 \mathrm{H}, 9 \mathrm{~A}$ infects $C$. demingiae ACAM $459^{\mathrm{T}}$; no other hosts (of 22 tested) were identified. In replete media, $9 \mathrm{~A}$ formed plaques on $34 \mathrm{H}$ from -6 to $4^{\circ} \mathrm{C}$ and on $C$. demingiae from -6 to $8^{\circ} \mathrm{C}_{;}$the temperature range of plaque formation on $34 \mathrm{H}$ could be extended to $8^{\circ} \mathrm{C}$ by prior host starvation. An indirect plating method and microscopic evaluation also determined phage production at temperatures between -13 and $-10^{\circ} \mathrm{C}$. At $-1{ }^{\circ} \mathrm{C}, 34 \mathrm{H}$ had a broader salinity range of plaque formation than C. demingiae: 20 to 50 (but not 65) psu vs. 27 to 34 (but not 50) psu. As monitored by epifluorescence microscopy, phage production by $34 \mathrm{H}$ was observed at 1, 10, 100 and $200 \mathrm{~atm}\left(\right.$ all at $-1^{\circ} \mathrm{C}$ ), but not at 400 or $600 \mathrm{~atm}$. The $9 \mathrm{~A}-34 \mathrm{H}$ system commonly had a low efficiency of plating (EOP; typically $~ 1 \%$ ) which varied with culture age. Despite repeated attempts, no meaningful adsorption rate could be determined at -1 or $8^{\circ} \mathrm{C}$. This result, the low EOP, and the effect of starvation on plaque formation suggest that fluctuating host phenotypes may play an important role in the dynamics of this system. One-step growth curves (using $34 \mathrm{H}$ as host) revealed a longer latent period ( 4 to 5 vs. 2.5 to $3 \mathrm{~h}$ ) and greater burst size (55 vs. 5 ) at -1 than $8^{\circ} \mathrm{C}$; at temperatures between -10 and $-12^{\circ} \mathrm{C}$, the estimated latent period was $5-10 \mathrm{~d}$ and the burst size 5. At both -1 and $8^{\circ} \mathrm{C}$, rise times were comparable to latent periods. Although the cycle from infection to burst at $-1^{\circ} \mathrm{C}$ required only 10 to $20 \%$ of the generation time of $34 \mathrm{H}$ at this temperature, the amount of viral DNA synthesized was comparable to the size of the host genome, suggesting very efficient and cold-active virus-encoded enzymes.
\end{abstract}

KEY WORDS: Virus - Phage 9A - Colwellia psychrerythraea 34H - Colwellia demingiae - Arctic · Adsorption $\cdot$ One-step growth curve $\cdot$ Pressure $\cdot$ Salinity

\section{INTRODUCTION}

Early viral research by Spencer $(1955,1960,1963)$ and later electron microscopic observations of high numbers of virus-like particles in seawater samples (Torella \& Morita 1979, Bergh et al. 1989) helped to dispel the presumption that bacteriophage were of little ecological significance in aquatic environments. Spencer $(1955,1960,1963)$, in particular, demonstrated phage infection of indigenous marine bacteria (rather than enteric hosts) specifically under conditions mimicking those in situ ( 3 to $4 \%$ salinity and $0^{\circ} \mathrm{C}$ ). Later workers have generally remained attentive to use of seawater salinities for marine phage-host cultivation but have overlooked Spencer's $(1955,1960,1963)$ emphasis on temperature, despite the predominance of cold waters $\left(\leq 4^{\circ} \mathrm{C}\right)$ at depth and high latitudes, as well as mounting evidence that viruses play active ecological roles in cold waters (Steward et al. 1996, GuixaBoixereu et al. 2002, Wells \& Deming 2006b) and sea ice (Wells \& Deming 2006a).

Symptomatic of this oversight is the absence of welldefined terminology for viruses capable of infection at low temperature. While these are often called 
'psychrophilic' (e.g. Stamatin 1963, Olsen 1967, Ackermann \& DuBow 1987) or 'psychrotrophic' (Greer 1982, 1983, Patel \& Jackman 1986), the terms are ambiguous or misleading, since they imply growth characteristics of the host, not features necessarily specific to the virus (e.g. the temperature range of infection by a given virus may change with different hosts). For the sake of clarity, we define as 'cold-active' those viruses capable of infection and production at $\leq 4^{\circ} \mathrm{C}$. This upper limit accords with the sparse literature about phage infection at low temperature and encompasses the temperatures of the perennially cold regions of the ocean. By this definition, several phage or phage-host systems (PHS) termed 'psychrophilic' or 'psychrotrophic' have not been demonstrated to be cold-active (e.g. Stamatin 1963, Whitman \& Marshall 1971a, Greer 1982, Patel \& Jackman 1986).

Beginning with Elder \& Tanner (1928), we have identified 29 cold-active phage from the literature, only a few of which have been investigated in any detail. Of these, the most extensively studied from a marine environment, Phage 27, was isolated from Boston seawater and formed plaques on its original host at 2 but not $20^{\circ} \mathrm{C}$ (Delisle \& Levin 1969). Further characterization determined that phage 27 was unusually thermolabile, had different maximal temperatures of plaque formation depending on its host $\left(<20^{\circ} \mathrm{C}\right.$ on Pseudomonas putrefaciens $\mathrm{P} 19 \mathrm{X}$ and $<26^{\circ} \mathrm{C}$ on $P$. putrefaciens P10; Delisle \& Levin 1972a) and highest efficiency of plating (EOP) on P19X at temperatures between -5 and $4^{\circ} \mathrm{C}$, decreasing 5 orders of magnitude at or above $10^{\circ} \mathrm{C}$ (Delisle \& Levin 1972b). Similar characteristics have been reported for cold-active phages from other environments (Olsen et al. 1968, Kulpa \& Olsen 1971, Greer 1983). Delisle \& Levin (1972b) also presented evidence that passage of the phage through different hosts at different temperatures altered its characteristics, including the temperature range of plaque formation.

Besides the work of Delisle \& Levin (1969, 1972a,b), no similarly comprehensive characterization of coldactive marine phages at low temperature has been reported, although recent, more limited work has supported their findings. A study by Middelboe et al. (2002) of a pelagic Arctic Pseuodoalteromonas PHS revealed a burst size $(\sim 18)$ and latent period $(\sim 15 \mathrm{~h})$ at $0{ }^{\circ} \mathrm{C}$ similar to those of Phage 27 on P19X at $2^{\circ} \mathrm{C}(\sim 10$ viruses and $14 \mathrm{~h}$, respectively; Delisle \& Levin 1972b). Borriss et al. (2003) determined that the temperature range of plaque formation for 3 PHS from Arctic sea ice was even more restrictive than that described by Delisle \& Levin (1972a), with no plaques observed at temperatures $\geq 10^{\circ} \mathrm{C}$ in one case. In general and regardless of environmental provenance, the maximum temperature of plaque formation by a cold-active phage tends to be lower than the maximum temperature for growth of the host (e.g. Spencer 1963, Wiebe \& Liston 1968, Whitman \& Marshall 1971b, Delisle \& Levin 1972a, Borriss et al. 2003).

Several studies of cold-active (but not necessarily marine) phages have also reported slower phage production rates, reduced burst sizes and longer latent periods at 3.5 to $4^{\circ} \mathrm{C}$ than at 25 to $26^{\circ} \mathrm{C}$ (Olsen et al. 1968, Kulpa \& Olsen 1971, Whitman \& Marshall 1971b, Sillankorva et al. 2004a). Unfortunately, some confusion surrounds these results, in particular those of Olsen et al. (1968). Using one of the same PHS (PX14Pseudomonas geniculata) as in Olsen et al. (1968), Olsen (1967) had reported that the highest burst size (300 to 350 ) occurred at $3.5^{\circ} \mathrm{C}$, not $25^{\circ} \mathrm{C}$, but only if the bacteria were grown at $3.5^{\circ} \mathrm{C}$ prior to infection. Later studies by other authors have also shown that the temperature of growth before infection can alter PHS characteristics at near-zero temperatures, including adsorption rate (Delisle \& Levin 1972b) and latent period (Sillankorva et al. 2004a), presumably due to host phenotypic changes accompanying growth at or transition to low temperature. With respect to one-step growth curves, however, Olsen et al. (1968), like Kulpa \& Olsen (1971) and even Delisle \& Levin (1972b), did not specify the pre-infection growth temperature. Olsen's (1967) and Olsen et al.'s (1968) data are in general agreement if one assumes that the 1968 host was grown at $25^{\circ} \mathrm{C}$ prior to infection; if so, determined characteristics of 'psychrophilic' phages may in part represent host reactions to dramatic temperature shifts.

In this paper, we focus attention on environmentally relevant but neglected variables affecting PHS, including temperature, salinity and pressure, by describing characteristics of a cold-active phage grown on 2 psychrophilic species of Colwellia, with most of our work focusing on host C. psychrerythraea Strain $34 \mathrm{H}$ (hereafter ' $34 \mathrm{H}^{\prime}$ ). The phage, 9A, was isolated from an Arctic nepheloid layer (a particle-rich region of the water column) against $34 \mathrm{H}$, itself originally cultured from Arctic shelf sediments (depth of $305 \mathrm{~m}_{i}$ Huston 2003). Although little is known about the quantitative ecology of Colwellia, they are routinely isolated from cold, particle- or surface-rich environments, including flounder eggs (D'Aoust \& Kushner 1972), sea ice (Junge et al. 2002, Borriss et al. 2003, Brinkmeyer et al. 2003) and nepheloid layers (Wells 2006); association with particles or surfaces is also supported by molecular approaches (DeLong et al. 1993, Gillan et al. 1998, Eilers et al. 2000, Bowman \& McCuaig 2003). With a growth temperature optimum among the coldest of cultivated psychrophiles (8 to $9^{\circ} \mathrm{C}_{i}$ Huston 2003) and its genome sequenced (Methé et al. 2005), 34H is an attractive organism with which to explore host and viral features enabling cold activity and their ecological consequences. 


\section{MATERIALS AND METHODS}

Field sampling and shipboard phage enrichment. Initial enrichment was conducted in Franklin Bay of the Canadian Arctic in October of 2002, aboard the NGCC 'Pierre Radisson' as part of the international Canadian Arctic Shelf Exchange Study (CASES). During our sampling period, Franklin Bay had a $\sim 40 \mathrm{~m}$ surface layer of brackish (23 to $24 \mathrm{psu}$ ) water, high concentrations of suspended particulate matter (maximum of $9.3 \mathrm{mg} \mathrm{l}^{-1}$ at the surface), and in places, a complicated nepheloid layer structure (Wells et al. 2006). For phage isolation, $40 \mathrm{l}$ of water were collected in rosette-mounted Niskin bottles from Stn $12\left(69.8^{\circ} \mathrm{N}, 126.1^{\circ} \mathrm{W}\right)$ on 12 October from a near-bottom nepheloid layer at $128 \mathrm{~m}$ depth and with an in situ temperature of approximately $-1^{\circ} \mathrm{C}$ t the corresponding water column profile (including transmissivity trace) is shown in Fig. 2B of Wells et al. (2006), where further sampling and site details are given. Once aboard ship, water was consolidated into two $201 \mathrm{car}-$ boys previously liberally rinsed with sample seawater, before transport to a $-1{ }^{\circ} \mathrm{C}$ laboratory for processing. There the water was gravity-filtered through a $0.2 \mu \mathrm{m}$ HT Tuffryn membrane capsule filter (effective filtration area of $500 \mathrm{~cm}^{2}$; Pall Gelman) to remove bacteria but not viruses. After filtration, which took $\sim 36 \mathrm{~h}$ due to the large volume, high particle load and small filter area, the water was divided into two carboys and enriched with 4 to $8 \mathrm{ml}$ each of turbid cultures of $34 \mathrm{H}$, Colwellia psychrerythraea NRC 1004, and sea-ice isolates 6M3 and 11B5 (putative Colwellia and Shewanella, respectively; Junge et al. 2002). Multiple hosts were used for enrichment in an attempt to avoid bias toward phage monovalence (Jensen et al. 1998). Yeast extract was also added to a final concentration of $1 \%$. After incubating at $-1^{\circ} \mathrm{C}$ for $4 \mathrm{~d}$, the seawater was again $0.2 \mu \mathrm{m}$ filtered before being concentrated to $\sim 90 \mathrm{ml}$ by ultrafiltration over a $30 \mathrm{kDa}$ cutoff, low-protein-binding, regenerated cellulose membrane (Prep/Scale TFF cartridge, nominal $0.23 \mathrm{~m}^{2}$ filter area; Millipore). This concentrate was $0.2 \mu \mathrm{m}$ filtered, diluted 1:1 in sterile phage buffer $(0.1 \mathrm{M} \mathrm{NaCl}, 50 \mathrm{mM}$ Tris- $\mathrm{HCl} \mathrm{pH}$ 8.0, $8 \mathrm{mM} \mathrm{MgSO}_{4}, 2 \mathrm{mM} \mathrm{CaCl}_{2}, 5 \%$ glycerol), stored and returned cold $\left(\leq 4^{\circ} \mathrm{C}\right)$ to the University of Washington to test against $34 \mathrm{H}$.

Phage isolation. To avoid exposure to high temperature, a modified isothermal version of the agar overlay technique for plaque assay was developed. A bottom layer of approximately 20 to $30 \mathrm{ml}$ of $50 \%$ marine broth 2216 (Difco) solidified with $1.5 \%$ bacto-agar (Difco) was overlaid with $3.6 \mathrm{ml}$ of a silica sol (generated as described by Dietz \& Yayanos 1978) enriched with a tryptone, glucose and yeast extract solution (TGY, where $10 \times$ TGY is $5 \mathrm{~g}$ tryptone, $2.5 \mathrm{~g}$ yeast extract, $1 \mathrm{~g}$ glucose in a total volume of $100 \mathrm{ml}$ distilled water), seeded with bacteria and phage, and gelled by the addition of salt (where 10× artificial sea water [ASW] is $24 \mathrm{~g} \mathrm{NaCl}, 0.7 \mathrm{~g}$ $\mathrm{KCl}, 5.3 \mathrm{~g} \mathrm{MgCl}_{2} \cdot 6 \mathrm{H}_{2} \mathrm{O}$ and $7 \mathrm{~g} \mathrm{MgSO}_{4} \cdot 7 \mathrm{H}_{2} \mathrm{O}$ in a total volume of $100 \mathrm{ml}$ distilled water). For convenience, we refer to this technique as a 'silica-gel overlay.' In a typical preparation, $2.7 \mathrm{ml}$ of silica sol $\left(\right.$ at $\left.2{ }^{\circ} \mathrm{C}\right)$ were normalized to a $\mathrm{pH}$ of $\sim 8.7$ with a few $\mu \mathrm{l}$ of $5 \mathrm{~N} \mathrm{NaOH}_{\text {; }}$ then, in the following sequence and at $2^{\circ} \mathrm{C}$ (or lower), $0.3 \mathrm{ml}$ of cold $0.2 \mu \mathrm{m}$ filtered 10× TGY, $0.3 \mathrm{ml}$ of cold $0.2 \mu \mathrm{m}$ filtered $10 \times \mathrm{ASW}$, and $0.3 \mathrm{ml}$ of a phage-bacteria suspension were added, with gentle head-over-tail mixing between each addition. Deviation from this sequence sometimes resulted in failed plates; moreover, the salt must be added before the phage-bacteria suspension to avoid osmotic shock. The final $\mathrm{pH}$ was 7.4 to 7.6. In side-by-side comparisons using cold-active viruses and a psychrophilic host, approximately five times more plaques, of generally larger size, were observed in silica-gel overlays than more traditional overlays with low melting point agarose.

For initial detection of infective phages, $100 \mu \mathrm{l}$ of concentrate were added to $300 \mu \mathrm{l}$ of a turbid bacterial suspension, plated as above and incubated at $2^{\circ} \mathrm{C}$. Within $3 \mathrm{~d}$, confluent lysis was detected. A dilution series was performed, with the result that plaques $\sim 0.5 \mathrm{~cm}$ in diameter had formed (again within $3 \mathrm{~d}$ at $2^{\circ} \mathrm{C}$ ) on the $10^{-4}$ dilution plate. Several plaques were picked by removing a small plug of gel and underlying agar with a sterile pipette tip and resuspending it in phage buffer. Thereafter a phage designated ' $9 \mathrm{~A}^{\prime}$ was plaque-purified by 3 successive platings. After the third plating, a high-titer phage stock was generated by incubating a nearly confluently lysed plate with $5 \mathrm{ml}$ of phage buffer at $2^{\circ} \mathrm{C}$ with gentle shaking. After $2 \mathrm{~d}$, the overlying buffer was removed with a sterile pipette, a few drops of chloroform were added to it and, after vigorous shaking, the chloroform was allowed to settle. Chloroform and cellular debris were removed by centrifugation for $20 \mathrm{~min}$ at $6000 \times g$ and $2^{\circ} \mathrm{C}$. The resultant bacteria-free stock was stored at 2 to $4^{\circ} \mathrm{C}$. This procedure typically yielded phage concentrations of $10^{10}$ to $10^{11} \mathrm{ml}^{-1}$, determined by staining with SYBR Gold and epifluorescence microscopy (see below).

Electron microscopy. Morphological characterization of Phage 9A was performed by transmission electron microscopy (TEM). Carbon-stabilized, formvar-coated, 300-mesh grids (Ted Pella) first rendered hydrophilic with $0.1 \%$ poly-lysine were floated for 10 min atop a $100 \mu \mathrm{l}$ drop of fresh lysate. After gently wicking the grid dry, it was stained for $60 \mathrm{~s}$ on a drop of $1 \%$ uranyl acetate, before again being wicked dry. Grids were viewed within $24 \mathrm{~h}$ on a Philips CM-100 $\mathrm{TEM}$ at an $80 \mathrm{kV}$ acceleration voltage and magnification of 130 to $180 \mathrm{~K}$. 
Estimation of genome size. Genome size was estimated by restriction fragment length polymorphism, as in Middelboe et al. (2002). DNA was extracted using a Lambda Midi Kit (Qiagen), following the manufacturer's instructions. Aliquots of 100 to $400 \mathrm{ng}$ phage DNA were digested for 1 to $2 \mathrm{~h}$ at $37^{\circ} \mathrm{C}$ with $5 \mathrm{U}$ of one of the following 10 enzymes (from Promega: HindIII, DraI, XbaI, RsaI; from Stratagene: EcoRI, BamHI, HaeIII; from New England Biolabs: MspI, BstUI; from Gibco BRL: PvuII), using manufacturer-supplied buffers and acylated BSA when indicated. Digests were visualized by electrophoresis on $0.8 \%$ agarose gels post-stained for 30 min with $0.01 \%$ buffered SYBR Green I (Molecular Probes).

Efficiency of plating (EOP). Efficiency of plating was determined by simultaneous quantification of phage by plaque assay, using the silica-gel overlay technique, and by epifluorescence microscopy. For the latter, the method of Noble \& Fuhrman (1998) as modified by Chen et al. (2001) was used. Briefly, a suitable volume of phage was diluted in cold $0.2 \mu \mathrm{m}$ filtered ASW amended with $1.5 \%$ formaldehyde, then filtered onto 25-mm, $0.02 \mu \mathrm{m}$ Anodisc filters (Whatman). The filtered ASW contained negligible viral numbers. Filters were stained with $100 \mu \mathrm{l}$ of $0.1 \%$ SYBR Gold (Molecular Probes) for 15 to $20 \mathrm{~min}$, dried by gently brushing the back of the filter against a kimwipe, and mounted on a glass slide with $30 \mu \mathrm{l}$ of medium containing $50 \%$ glycerol, $50 \%$ phosphate-buffered saline and $0.1 \%$ $p$-phenylenediamine. Slides were counted on a Zeiss Universal microscope at $1563 \times$ magnification.

Preliminary experiments to assess phage titers determined by plaque count versus microscopy found considerable variability, despite standardizing bacterial growth and phage infection conditions. To examine this variability further, an experiment was performed to measure changes in EOP at $-1^{\circ} \mathrm{C}$ over short periods of time (less than 1 doubling period). A volume of $90 \mathrm{ml}$ of mid-exponential $34 \mathrm{H}$, grown at $-1{ }^{\circ} \mathrm{C}$, was passed through a Type A/E glass fiber filter (Gelman, nominal pore size of $1.0 \mu \mathrm{m}$, sterilized by autoclaving) to remove large cells, including those on the verge of dividing. The filtrate of small cells was then incubated at $-1^{\circ} \mathrm{C}$ until again reaching mid-exponential phase, as monitored by absorbance at $600 \mathrm{~nm}$. The culture was filtered a second time as before and distributed in $30 \mathrm{ml}$ aliquots to three $50 \mathrm{ml}$ sterile polypropylene tubes. These tubes were incubated at $-1^{\circ} \mathrm{C}$ without addition of phage 9A. Subsamples from each replicate were removed daily for $3 \mathrm{~d}$ and challenged with a dilution series of phage, plated using the silica-gel overlay technique and incubated at $2^{\circ} \mathrm{C}$. The same phage stock was used for all time points and, to be consistent with the rest of the experiment, was stored at $-1^{\circ} \mathrm{C}$ in the interim. At each time point, bacterial concentration and the frequency of dividing cells were determined from 0.1-ml subsamples using SYBR-staining and epifluorescence microscopy. At the start of the experiment, the phage stock was quantified by SYBR-staining; no appreciable decay of viruses was observed over these time periods at $-1^{\circ} \mathrm{C}$ (Wells \& Deming 2006c, this issue)

Host range determined by plaque formation. Plaque formation by $9 \mathrm{~A}$ was assayed against 21 bacterial isolates of marine origin besides $34 \mathrm{H}$ (see Table 1) using the silica-gel overlay technique and 2 temperatures, -1 and $8^{\circ} \mathrm{C}$, representing the in situ and optimal growth temperatures of $34 \mathrm{H}$. Prior to infection prospective hosts were grown in $50 \%$ marine broth 2216 to early or mid-exponential phase at the same temperature as the plaque assay (including phage adsorption). They were then concentrated 5-fold by centrifugation and plated against 9A, employing a dilution series if no lawns developed. All experiments included negative (no phage added) and positive $(34 \mathrm{H}+9 \mathrm{~A})$ controls. In 2 cases (Colwellia rossensis, grown at $-1^{\circ} \mathrm{C}$, and $C$. hornerae, grown at $8^{\circ} \mathrm{C}$ ), starved bacteria were tested for altered susceptibility to phage infection. For starvation, the bacteria were pelleted, rinsed with cold ASW, resuspended in ASW and held on ice for $6 \mathrm{~h}$. Following addition of $9 \mathrm{~A}$, plates were poured as usual and incubated at $8^{\circ} \mathrm{C}$.

Temperature and salinity ranges of plaque formation. The temperature range of plaque formation was tested using the silica-gel overlay technique at a salinity of $34 \mathrm{psu}$. The temperatures examined were $-6,-3$, $-1,2,4,8,13$ and $18^{\circ} \mathrm{C}\left( \pm 1^{\circ} \mathrm{C}\right.$ for each $)$, corresponding to the known range of growth by $34 \mathrm{H}$ under these conditions (Huston 2003). For each experiment, bacteria were grown at $-1^{\circ} \mathrm{C}$ prior to infection; to check for effects due to temperature shift, a few experiments were also conducted with $34 \mathrm{H}$ grown at $8^{\circ} \mathrm{C}$. In all cases, early to mid-exponential cells $(600 \mathrm{~nm}$ absorbance typically at 0.3 ) were concentrated 5-fold by centrifugation in $50 \%$ marine broth 2216 and infected with a suitable dilution of phage. Approximately $30 \mathrm{~min}$ were allotted for adsorption before plating, followed by incubation at the given temperature until plaques or a lawn were observed (typically 1 to $2 \mathrm{wk}$, depending on temperature). At $-1,8$ and $13^{\circ} \mathrm{C}$, we tested whether prior starvation in ASW (as already described) for 4,29 or $53 \mathrm{~h}$ at $-1^{\circ} \mathrm{C}$ affected the temperature range. Because of indications of phage production without plaque formation, we also examined viral production at 8 and $13^{\circ} \mathrm{C}$ by SYBR staining and microscopy.

The salinity range was assessed at $-1^{\circ} \mathrm{C}$ following Huston (2003). A basal medium consisting $\left(\mathrm{l}^{-1}\right.$ of distilled water) of $3 \mathrm{~g}$ peptone, $1.2 \mathrm{~g}$ yeast extract, $6 \mathrm{mg}$ $\mathrm{FePO}_{4}$ and $3 \mathrm{mM}$ TAPSO (3-[N-tris(hydroxymethyl) 
methylamino]-2-hydroxy-propanesulfonic acid) buffer, pH 7.2 was modified with $10 \times$ ASW to obtain salinities from 50 to $200 \%$ of normal seawater salinity (in the terms reported by Huston 2003), equivalent to 20-65 psu as determined by refractometer. These salinities correspond to the salinity range of growth by $34 \mathrm{H}$ at $-1^{\circ} \mathrm{C}$ under these conditions (Huston 2003) and represent an environmentally realistic range from brackish water (as seen at Stn 12 due to riverine input and ice melt; Fig. 2B in Wells et al. 2006) to the mild brines of relatively warm $\left(-3^{\circ} \mathrm{C}\right)$ sea ice. Prior to infection, $34 \mathrm{H}$ was grown at the experimental salinity through at least 1 transfer, then concentrated and infected as described above. For the silica-gel overlay plates, both the agar bottom layer and the silica-gel overlay were adjusted to the experimental salinity. At the highest salinity (200\%, or 65 psu), the silica-gel overlays gelled poorly, so phage production was assayed in broth instead and evaluated by SYBR-staining and epifluorescence microscopy.

Finally, because 9A also infects Colwellia demingiae ACAM 459 ${ }^{\mathrm{T}}$, we determined the temperature and salinity ranges of plaque formation on it, as above. All experiments with either host included negative (no phage added) and positive $(34 \mathrm{H}+9 \mathrm{~A}$ under conditions permissive of phage production) controls.

Phage production between -10 and $-13^{\circ} \mathrm{C}$. Two experiments were conducted in an incubator maintaining a temperature between -10 and $-12^{\circ} \mathrm{C}$ (first experiment) or -12 and $-13^{\circ} \mathrm{C}$ (second experiment), as validated by both a low temperature thermometer and a thermocouple probe. Because plates froze at $<-6^{\circ} \mathrm{C}$, the procedure outlined above was not viable. Instead, for the first experiment, changes in the concentration of plaque-forming units (PFU) were assayed indirectly as follows: $40 \mathrm{ml}$ of early-exponential $34 \mathrm{H}$ (pre-grown at $-1^{\circ} \mathrm{C}$ ) were concentrated 2-fold in fresh, cold and $0.2 \mu \mathrm{m}$ filtered, $50 \%$ marine broth 2216. Phage 9A was added at a multiplicity of infection (MOI) of 2 (determined by SYBR-staining and epifluorescence microscopy) and allowed to adsorb for $10 \mathrm{~min}$ on ice. The cells were then pelleted again, the virus-containing supernatant was poured off, and the visible pellet was gently washed three times with $5 \mathrm{ml}$ of the broth. After the last wash, the bacteria were resuspended in $15 \mathrm{ml}$ of broth and $1 \mathrm{ml}$ aliquots were dispensed into sterile Eppendorf microfuge tubes for incubation at $-10^{\circ} \mathrm{C}$. Three were sacrificed to measure concentrations of PFU at time $t=0$, by plating on uninfected bacteria at $2^{\circ} \mathrm{C}$. Thereafter, the remaining tubes were sacrificed in groups of three (chosen randomly and regardless of whether the samples had frozen) after 5, 10 and $15 \mathrm{~d}$ and plated as above. Frozen samples were thawed and processed as soon as the last ice crystal melted. An uninfected $34 \mathrm{H}$ control was also incubated at $-10^{\circ} \mathrm{C}$ and periodically assayed for plaque formation. Because of variability in EOP over such an extended time period (see 'Results' subsection; 'Efficiency of plating' below), a sample of phage with no added bacteria was set aside $\left(\right.$ at $-1^{\circ} \mathrm{C}$ ) and plated at each time point to serve as a standard. The stability of phage stocks for $>6$ mo at temperatures $\leq 4^{\circ} \mathrm{C}$ indicated that decay of the plating standard over the $2 \mathrm{wk}$ experiment at $-1^{\circ} \mathrm{C}$ should be negligible.

To address phage production specifically in liquid samples below $-10^{\circ} \mathrm{C}$, a second experiment was performed in which bacterial and viral concentrations were monitored by epifluorescence microscopy. Midexponential $34 \mathrm{H}$ was diluted $1: 8$ in cold $50 \% 2216$ and infected with 9A to an MOI of 1.5. After gentle mixing, $1 \mathrm{ml}$ aliquots of infected culture were dispensed into 18 sterile $1.5-\mathrm{ml}$ microcentrifuge tubes. At $t=0$ and every 3 to $5 \mathrm{~d}$ for $1 \mathrm{mo}, 100 \mu \mathrm{l}$ were taken from a tube containing liquid sample and fixed into $3 \mathrm{ml}$ ice-cold, $0.2 \mu \mathrm{m}$ filtered ASW amended with formaldehyde (1.5\% final concentration). The samples were immediately filtered onto 0.02- $\mu \mathrm{m}$ Anodiscs, stained as above with SYBR Gold and counted within $24 \mathrm{~h}$. During the first half of the experiment, a liquid-containing tube was selected at random for each time point. By Day 18, only a single tube remained unfrozen (sampled on Day 14). To conserve volume, $50 \mu \mathrm{l}$ was subsampled repeatedly from this tube for the remaining time points.

Phage production under hydrostatic pressure. To determine the pressure range of phage production at $-1^{\circ} \mathrm{C}, 34 \mathrm{H}$ was grown at $1 \mathrm{~atm}$ and $-1^{\circ} \mathrm{C}$ to mid-exponential phase. The culture was then diluted 1:10 in fresh media and split into two $11 \mathrm{ml}$ batches kept on ice. One batch was left untreated as a control; the other received $9 \mathrm{~A}$ at a final concentration of $3 \times 10^{7} \mathrm{ml}^{-1}$ (MOI of 3). After gentle head-over-tail mixing of each split, small aliquots were fixed in cold ASW amended with formaldehyde (1.5\% final conc.) to measure initial abundances of bacteria and viruses by SYBR staining (as above). Sample volumes of $0.7 \mathrm{ml}$ were then dispensed into sterile, $0.7 \mathrm{ml}$ microfuge tubes with caps removed and sealed with parafilm (leaving no headspace). Two samples, 1 with phage and 1 without, were incubated at $1 \mathrm{~atm}$ and $-1^{\circ} \mathrm{C}$; the remaining, in sets of two for control and treatment, were pressurized to 10 , $100,200,400$ or 600 atm, using stainless steel pressure vessels and distilled water as the hydraulic fluid (Deming 2001). At $8^{\circ} \mathrm{C}, 34 \mathrm{H}$ is known to grow at pressures of 1 to $400 \mathrm{~atm}$, although no significant growth has been detected at $600 \mathrm{~atm}$ (R. E. Collins, J. G. Marx \& J. W. Deming unpubl. data). From the time of phage addition, $1 \mathrm{~h}$ elapsed before all samples were pressurized and incubating at $-1^{\circ} \mathrm{C}$. For each end-point experiment at a given pressure, 2 vessels were used. One was decompressed after $24 \mathrm{~h}$ to estimate (by SYBR- 
staining and epifluorescence microscopy) short-term bacterial and viral changes associated with the increased pressure and subsequent decompression. The other was incubated for $3 \mathrm{~d}$ ( 1 and $10 \mathrm{~atm}), 7 \mathrm{~d}$ (100 and $200 \mathrm{~atm})$ or $14 \mathrm{~d}(400$ and $600 \mathrm{~atm})$ at $-1^{\circ} \mathrm{C}$ before decompression and phage and bacterial enumeration. Incubation times were varied at different pressures to accommodate corresponding differences in $34 \mathrm{H}$ growth rate.

Adsorption experiments. Two methods were used to measure phage adsorption to $34 \mathrm{H}$, the first relying upon PFU assays and the second on SYBR counts. In both, 9A was added to $3-5 \mathrm{ml}$ of early exponential $34 \mathrm{H}$ culture $\left(\sim 10^{8}\right.$ cells $\left.\mathrm{ml}^{-1}\right)$ grown at $-1,2$ or $8^{\circ} \mathrm{C}$, depending on the experiment. MOI ranging from $\sim 0.1$ to $\sim 10$ and incubation periods (on ice or at $8^{\circ} \mathrm{C}$ ) from 5 to $180 \mathrm{~min}$ were tested. Periodically during the incubations, $0.1 \mathrm{ml}$ aliquots were removed and diluted 1:100 in cold 50\% marine broth 2216 to stop adsorption. After gentle mixing, cells were pelleted by centrifugation from a subsample of this dilution. In the PFU method, the supernatant was assayed for unadsorbed phage using the silica-gel overlay technique, while in the SYBR method, viruses were enumerated by epifluorescence microscopy as above; i.e., the sample was fixed in ASW amended with formaldehyde $1.5 \%$ final conc.) following the centrifugation step. For the PFU method, the sample was centrifuged at $3000 \times g$ for $5 \mathrm{~min}$. For the SYBR method, it was centrifuged at higher speed and duration, $15000 \times g$ for $10 \mathrm{~min}$, because the presence in the supernatant of even a small fraction of the total cells (which did not affect interpretation of the results of the PFU method) led to occlusion of the field of view for counting viruses. The MOI was determined by plating the phage stock (PFU method) or by counting viruses (SYBR method) and bacteria (both methods) using epifluorescence microscopy. Because of the low EOP (see below), MOI determined by plaque counts may have underestimated true MOI by as much as 100 -fold.

One-step growth curves. One-step growth curves were determined at -1 and $8^{\circ} \mathrm{C}$, using a protocol modified from Adams (1959); all steps were done at the experimental temperature, including growing the initial culture of $34 \mathrm{H}$. Briefly, $1 \mathrm{ml}$ of early exponential $34 \mathrm{H}$ was infected with $9 \mathrm{~A}$ at a MOI of $\sim 1$ at $8^{\circ} \mathrm{C}$ (determined by SYBR-staining) or 3 at $-1^{\circ} \mathrm{C}$ (by PFU). After $10 \mathrm{~min}$ for adsorption, the bacteria and phage were diluted 1:10 in 50\% marine broth 2216 and immediately centrifuged to pellet cells. After removing the phage-containing supernatant, the cells were washed and resuspended in fresh growth media. This tube was called the 'experimental tube.' It was then diluted serially in increments of 1:10 to generate the 'first growth tube,' 'second growth tube,' etc., up to a 'fifth growth tube.' Multiple growth tubes were used because the fraction of infected bacteria could not be calculated in advance. At $t=0$, a dilution series of the experimental tube was plated by silica-gel overlay to determine the initial number of infected bacteria. Dilutions of each growth tube (1:10 and 1:100) were also plated at $t=0$ and at regular intervals thereafter to measure phage production. The multiple growth tubes and different dilutions provided a series of redundant (but, strictlyspeaking, not replicate) measurements at each time point. For both experiments, plates were incubated at $2{ }^{\circ} \mathrm{C}$.

\section{RESULTS}

\section{Morphological characterization}

Examination of 9A by TEM revealed it to be a tailed phage (Fig. 1). The capsid diameter is $90 \mathrm{~nm}$ in its longest dimension, with a tail length of $\sim 200 \mathrm{~nm}$. The tail does not appear to be contractile.

\section{Genome size}

The enzymes EcoRI, PvuII and BstU1 yielded qualitatively similar digests, with 10 to 11 fragments of similar size, ranging from $\sim 3$ to $22 \mathrm{~kb}$. The sum of fragments suggests a genome size of 80 to $90 \mathrm{~kb}$. For the DraI and HindIII digests, the range of fragment sizes was $<2$ to $\sim 6 \mathrm{~kb}$, implying a smaller genome of $40 \mathrm{~kb}$; however, a large number of small fragments may have gone undetected. Phage DNA was not digested by XbaI, BamHI, HaeIII, MspI or PvuII.

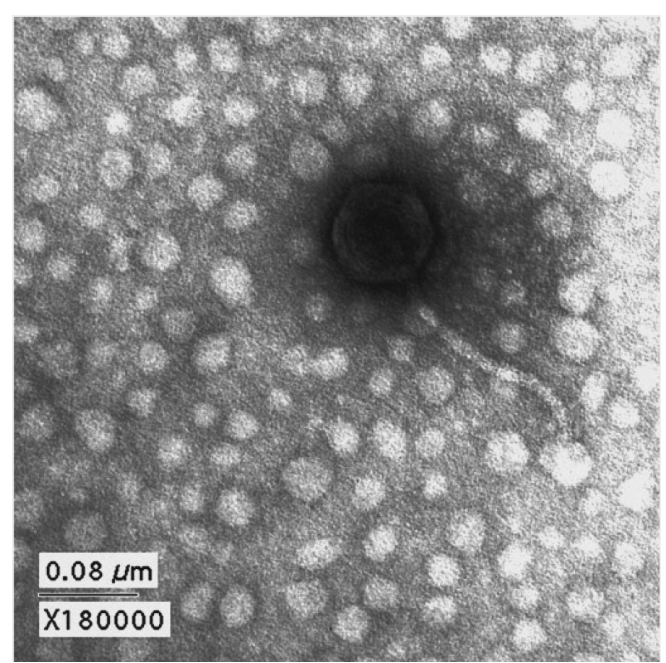

Fig. 1. Transmission electron micrograph of Phage 9A 


\section{Efficiency of plating}

The EOP, routinely determined by comparing counts of SYBR-stained viruses and of PFU, was typically at or below $1 \%$ at $-1^{\circ} \mathrm{C}$. Because it occasionally varied more widely and once reached $74 \%$, vacillating for a $2 \mathrm{wk}$ period thereafter between 1.5 and 27\% (data not shown), changes in EOP were evaluated over $3 \mathrm{~d}$ at $-1^{\circ} \mathrm{C}$. EOP was highest at the start of the experiment $(1 \%)$ and declined linearly with time $(p<0.009)$ to $0.2 \%$ at the end of the experiment (Fig. 2). Over that time period, the $34 \mathrm{H}$ population increased by a factor of only 1.6 (Fig. 2). Although cell growth was not synchronized, the attempt to remove large and dividing cells by $1.0 \mu \mathrm{m}$ filtration was relatively successful, given the low concentration $\left(1.8 \times 10^{6} \mathrm{ml}^{-1}\right)$ and frequency of dividing cells $(4 \%)$ at the start of the experiment (Fig. 2). Concentrations of dividing cells increased rapidly over the first day (by a factor of 7 ; Fig. 2), but then stabilized, with a relatively constant frequency over the final $2 \mathrm{~d}$ (15 to $20 \%$ ).

\section{Range of hosts supporting plaque formation}

Of 21 bacterial cultures (besides $34 \mathrm{H}$ ) against which Phage 9A was tested, no other characterized or probable strains of Colwellia psychrerythraea were susceptible (Table 1), although induction of a temperate phage from a probable strain (53A3) increased if 9A was pre-

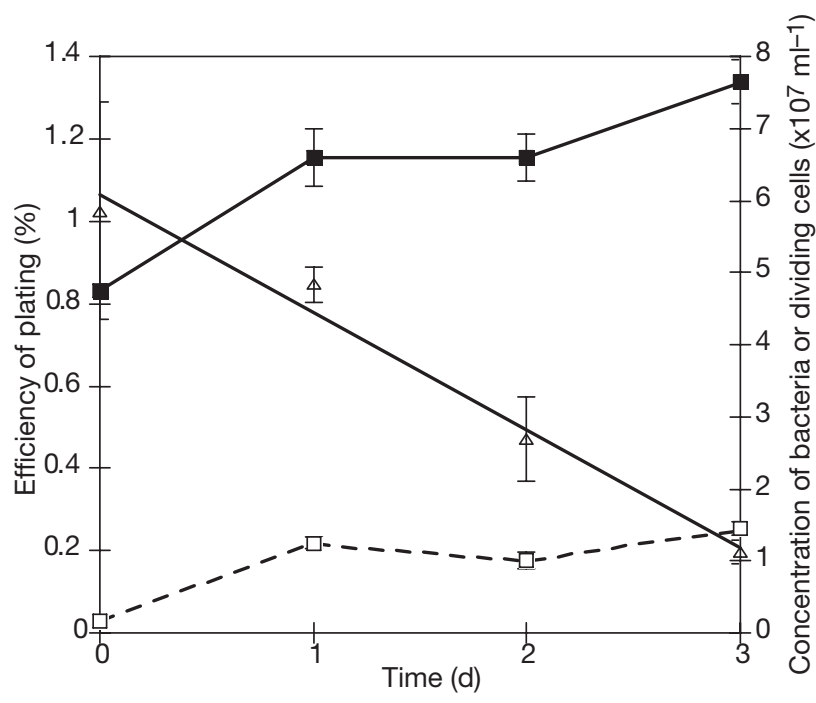

Fig. 2. Change in efficiency of plating (EOP) ( $\Delta$ and regression line) and the concentrations of bacteria ( $\mathbf{\square})$ and dividing cells ( $\square$ ) with time. Regression equation is EOP $(\%)=-0.29 \times$ time $(\mathrm{d})+1.1 ; \mathrm{p}<0.009$. Error bars represent $\pm \mathrm{SE}$ of the mean of triplicate samples (where not visible, bars are smaller than the width of the symbol) sent (see Wells 2006 for further details). Within the Colwellia genus, 9A could infect $C$. demingiae ACAM $459^{\mathrm{T}}$ at both -1 and $8^{\circ} \mathrm{C}$. No other hosts were identified among the other marine bacteria assayed, nor did prior starvation result in susceptibility to 9A for either $C$. rossensis ACAM $608^{\mathrm{T}}$ or $C$. hornerae ACAM $607^{\mathrm{T}}$ under the conditions tested.

\section{Temperature range of plaque formation}

When $34 \mathrm{H}$ was grown at $-1^{\circ} \mathrm{C}$ prior to infection, 9A formed plaques on silica-gel plates from -6 to $4^{\circ} \mathrm{C}$ but not at $8^{\circ} \mathrm{C}$ (Table 2). Prior growth at $8^{\circ} \mathrm{C}$ did not change the temperature range, but the number of plaques was usually reduced considerably. The temperature range of plaque formation could be extended to $8^{\circ} \mathrm{C}$ by prior starvation of $34 \mathrm{H}$ (whether for 4,29 or $53 \mathrm{~h}$ ), although the plaques were smaller than usual. Given these results, SYBR-staining and epifluorescence microscopy were used to assess whether viral production persisted under non-starvation conditions at 8 and $13^{\circ} \mathrm{C}$, despite the absence of plaque formation. Over $24 \mathrm{~h}$, viral concentrations increased an order of magnitude at $8^{\circ} \mathrm{C}$; no increase was seen at $13^{\circ} \mathrm{C}$.

Colwellia demingiae ACAM $459^{\mathrm{T}}$ had a broader temperature range of plaque formation than $34 \mathrm{H}$ (without prior starvation), from -6 to at least $8^{\circ} \mathrm{C}$ (Table 2), despite the 2 bacteria having similar cardinal growth temperatures (Bowman et al. 1998). Weak growth in silica-gel overlays at $\geq 13^{\circ} \mathrm{C}$ prevented determination of the upper temperature limit of plaque formation, however.

\section{Salinity range of plaque formation}

Over the salinity range for robust growth of $34 \mathrm{H}$ (50 to $150 \%$ seawater, or 20 to $50 \mathrm{psu}$ ), 9A also produced plaques on $34 \mathrm{H}$ (Table 3 ). Comparable numbers of plaques were observed at all salinities. At $200 \%$ seawater salinity (65 psu), growth of $34 \mathrm{H}$ was weak, as reported previously (Huston 2003). Silica-gel overlays were not effective at this salinity, but SYBR-staining and epifluorescence microscopy revealed no evidence of viral production over a $3 \mathrm{~d}$ period.

Colwellia demingiae ACAM $459^{\mathrm{T}}$ appeared to have a narrower salinity range for plaque formation (but not growth) than $34 \mathrm{H}$ (Table 3). Plaques were observed at 75 and $100 \%$ seawater salinity (27 and 34 psu); a lawn was observed at $150 \%$ (50 psu). At $50 \%$ (20 psu), C. demingiae ACAM $459^{\mathrm{T}}$ grew too weakly in silica-gel overlays to determine whether plaques had formed. 
Table 1. Marine bacteria tested against Phage 9A for plaque formation on silica-gel overlay plates incubated at -1 or $8^{\circ} \mathrm{C}$. Cultures were grown at the plaque assay temperature. +: plaques observed; -: no plaques observed (bacterial lawn); wg: bacterial growth too weak or variable for a definitive assay; ng: below the bacterium's minimum temperature for growth; nd: not determined; UT: University of Tasmania; UW: University of Washington; JCM: Japan Collection of Microorganisms; ATCC: American Type Culture Collection; IMB: Institut für Marine Biotechnologie

\begin{tabular}{|c|c|c|c|}
\hline \multirow[t]{2}{*}{ Culture } & \multirow[t]{2}{*}{ Source } & \multicolumn{2}{|c|}{ Plaque formation } \\
\hline & & $-1^{\circ} \mathrm{C}$ & $8^{\circ} \mathrm{C}$ \\
\hline \multicolumn{4}{|l|}{ Characterized Colwellia spp. } \\
\hline C. psychrerythraea NRC 1004 & ATCC & wg & - \\
\hline C. psychrotropica ACAM $179^{\mathrm{T}}$ & J. Bowman, UT & - & - \\
\hline C. demingiae ACAM $459^{\mathrm{T}}$ & J. Bowman, UT & + & + \\
\hline C. demingiae ICP 10 & J. Bowman, UT & - & - \\
\hline C. hornerae ACAM $607^{\mathrm{T}}$ & J. Bowman, UT & - & - \\
\hline C. maris JCM 10085 & $\mathrm{JCM}$ & - & - \\
\hline C. rossensis ACAM $608^{\mathrm{T}}$ & J. Staley, UW & - & - \\
\hline \multicolumn{4}{|c|}{ Probable Colwellia (uncharacterized but for $16 \mathrm{~S}$ rRNA analysis) } \\
\hline Arctic surface-water isolate $53 \mathrm{~A}^{\mathrm{a}}$ & This laboratory (UW) & $-{ }^{\mathrm{b}}$ & $-{ }^{\mathrm{b}}$ \\
\hline Arctic nepheloid layer isolate $75 \mathrm{C}^{\mathrm{a}}$ & This laboratory (UW) & - & - \\
\hline \multirow[t]{2}{*}{ Arctic sea-ice isolate $21 \mathrm{C}^{c}$} & M. Borriss \& T. Schweder, IMB & & \\
\hline & Greifswald, Germany (Borriss et al. 2003) & - & - \\
\hline Arctic sea-ice isolate $6 \mathrm{M} 3$ & This laboratory (Junge et al. 2002) & - & - \\
\hline \multicolumn{4}{|l|}{ Other characterized Bacteria } \\
\hline Idiomarina abyssalis KMM 227 & ATCC & - & - \\
\hline Idiomarina zobellii KMM 231 & ATCC & $\mathrm{ng}$ & - \\
\hline Halomonas pacifica & J. Kaye \& J. Baross, UW & ng & - \\
\hline Halomonas aquamarina & J. Kaye \& J. Baross, UW & ng & - \\
\hline Planomicrobium mcmeekinii & This laboratory (UW) & - & - \\
\hline \multicolumn{4}{|c|}{ Other uncharacterized Bacteria (but for 16S rRNA analysis) } \\
\hline $\begin{array}{l}\text { Marine isolate NP9 } \\
\text { (putative Vibrio) }\end{array}$ & B. van Mooy \& A. Devol, UW & $\mathrm{ng}$ & - \\
\hline $\begin{array}{l}\text { Arctic sea-ice isolate 11B5 } \\
\text { (putative Shewanella) }\end{array}$ & $\begin{array}{l}\text { This laboratory (UW) } \\
\text { (Junge et al. 2002) }\end{array}$ & _- & _- \\
\hline $\begin{array}{l}\text { Arctic sea-ice isolate } 4 \mathrm{~B} 3 \\
\text { (putative } \alpha \text {-Proteobacterium) }\end{array}$ & $\begin{array}{l}\text { This laboratory (UW) } \\
\text { (Junge et al. 2002) }\end{array}$ & nd & - \\
\hline \multicolumn{4}{|c|}{ Uncharacterized bacteria of uncertain affiliation } \\
\hline Arctic sea-ice isolate $7 \mathrm{~W} 1$ & This laboratory (UW) & - & - \\
\hline $\begin{array}{l}\text { Arctic nepheloid layer isolate } 12 \mathrm{~S} 3 \\
\text { (from same water sample as } 9 \mathrm{~A} \text { ) }\end{array}$ & This laboratory (UW) & nd & - \\
\hline \multicolumn{4}{|c|}{ 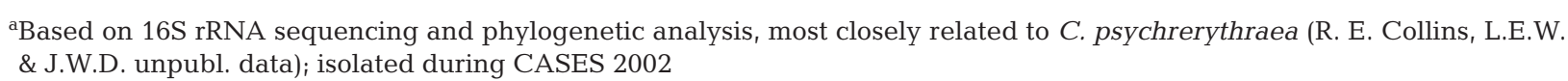 } \\
\hline \multicolumn{4}{|c|}{$\begin{array}{l}\text { bIsolate 53A3 is a known lysogen (Wells 2006): plaque counts increased in the presence of 9A, but the plaques were turbid } \\
\text { Identified by Borriss et al. (2003) as most closely affiliated with C. psychrerythraea or C. demingiae }\end{array}$} \\
\hline
\end{tabular}

\section{Phage production between -13 and $-10^{\circ} \mathrm{C}$}

The intention of the first experiment between -10 and $-12^{\circ} \mathrm{C}$ was to measure phage production in a frozen sample, presumably within the brine inclusions formed during freezing (Junge et al. 2001, Wells \& Deming 2006a). Surprisingly, only about half of the experimental samples froze, even after $15 \mathrm{~d}$. Failure to freeze may reflect an absence of ice-nucleation events: in this case, neither $34 \mathrm{H}$ nor 9A has substantial icenucleating ability (K. Junge pers. comm.) and we were using $0.2 \mu \mathrm{m}$ filtered broth. In any event, these circumstances enabled us to compare phage production at $-10^{\circ} \mathrm{C}$ in liquid medium vs. ice. Considering average concentrations of PFU (scaled to the plating standard, as described in 'Materials and methods') for triplicate samples at each time increment, no change was observed after $5 \mathrm{~d}$, but the concentrations had increased 5-fold after $10 \mathrm{~d}$, declining by half thereafter (Fig. 3A). If these data are segregated according to liquid vs. frozen samples, the increases in PFU concentration were significant only in the tubes that remained liquid (Fig. 3A). Again, no change was observed during the first $5 \mathrm{~d}$, but concentrations in liquid samples on Days 10 and 15 were 6- to 7 -fold greater (and comparable to each other). 
Table 2. Phage 9A. Range of temperatures at which 9A forms plaques on Colwellia psychrerythraea $34 \mathrm{H}$ or C. demingiae ACAM 459 in 50\% marine broth 2216 (34 psu), including after starvation in ASW. Hosts were grown at $-1^{\circ} \mathrm{C}$ prior to infection. +: plaques observed; -: no plaques observed (bacterial lawn); wg: host growth too weak or variable for a definitive assay. nd: not determined

\begin{tabular}{lccc}
\hline $\begin{array}{l}\text { Test temp. } \\
\left({ }^{\circ} \mathrm{C}\right)\end{array}$ & $34 \mathrm{H}$ & $\begin{array}{r}\text { Test culture } \\
\text { Starved } 34 \mathrm{H}\end{array}$ & 459 \\
\hline-6 & + & nd & + \\
-3 & + & nd & + \\
-1 & + & + & + \\
2 & + & nd & + \\
4 & + & nd & + \\
8 & $-{ }^{\mathrm{a}}$ & + & + \\
13 & $-{ }^{\mathrm{b}}$ & - & wg \\
18 & wg & nd & nd
\end{tabular}

${ }^{a}$ Phage production was detected microscopically by SYBRstaining

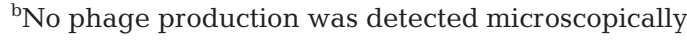

Table 3. Phage 9A. Range of salinities at which 9A forms plaques on Colwellia psychrerythraea $34 \mathrm{H}$ or C. demingiae ACAM 459 at $-1^{\circ} \mathrm{C}$. +: plaques observed; -: no plaques observed (bacterial lawn); wg: bacterial growth was too weak or variable for a definitive assay. nd: not determined

\begin{tabular}{|lccc|}
\hline \multicolumn{2}{c}{ Salinity } & \multicolumn{2}{c}{ Test culture } \\
$\%$ seawater & psu & $34 \mathrm{H}$ & 459 \\
\hline 50 & 20 & + & $\mathrm{wg}$ \\
75 & 27 & + & + \\
100 & 34 & + & + \\
150 & 50 & + & - \\
200 & 65 & $-^{\mathrm{a}}$ & nd
\end{tabular}

aSilica-gel overlays gelled poorly at this salinity and could not be used. No phage production was detected microscopically

In the second experiment designed to consider changes in viral and bacterial concentrations in liquid samples only, the incubator maintained slightly colder temperatures of -12 to $-13^{\circ} \mathrm{C}$. As before, several samples remained liquid at this temperature for up to $2 \mathrm{wk}$ and one remained so for the 1 mo experiment. Over the first $11 \mathrm{~d}$, both viral and bacterial concentrations declined (Fig. 3B). Thereafter, the bacteria increased 6 -fold over a 2 wk period, while viruses showed steplike increases of $\sim 4 \times 10^{6}$ viruses $\mathrm{ml}^{-1}$ and $7 \times 10^{6}$ viruses $\mathrm{ml}^{-1}$ on Days 14 and 27, respectively (Fig. 3B). On Day 32 bacteria but not viruses had begun to decline.
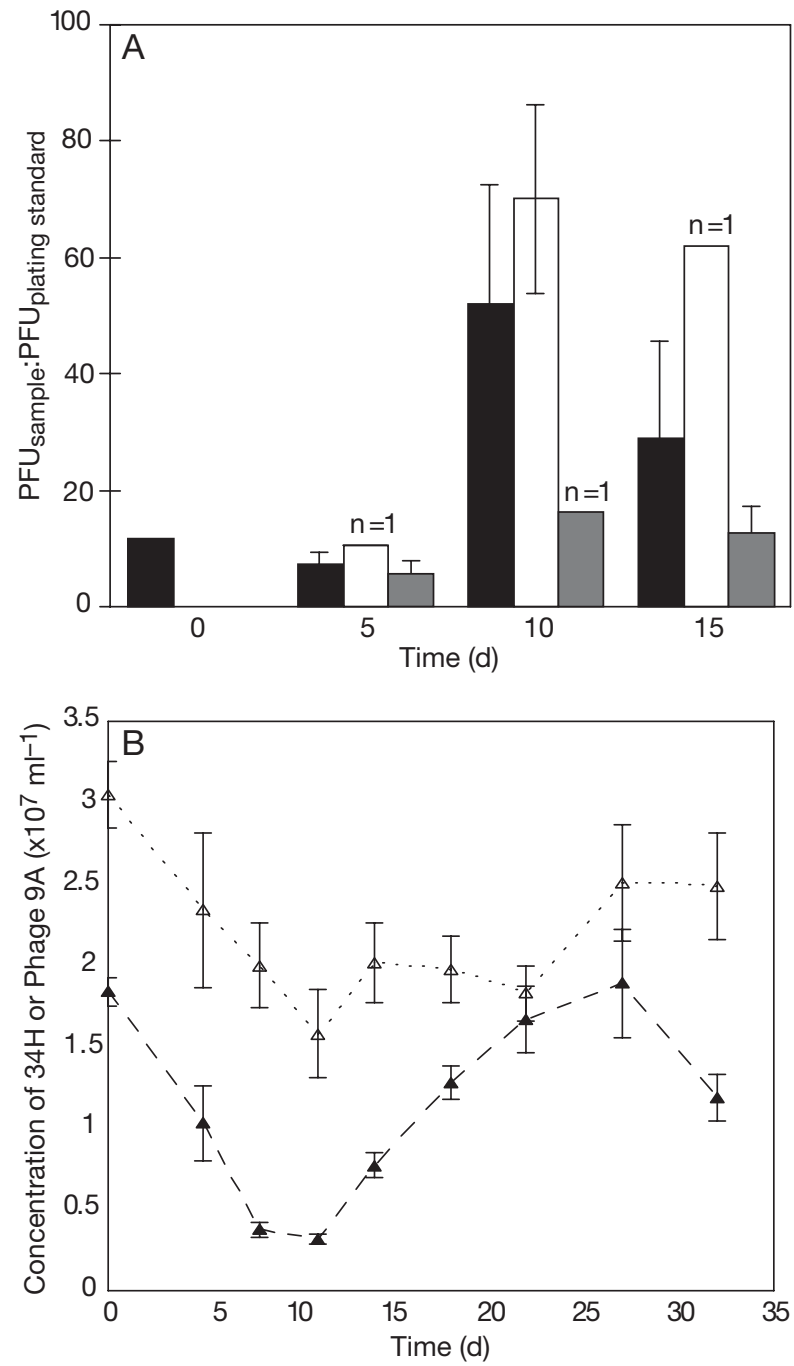

Fig. 3. (A) Phage 9A. Phage production during incubation at temperatures between -10 and $-12^{\circ} \mathrm{C}$, where phage abundance was assayed by ability to form PFU at $2^{\circ} \mathrm{C}$ and then normalized to a plating standard (see 'Materials and methods'), yielding the ratio $\mathrm{PFU}_{\text {sample: }} \mathrm{PFU}_{\text {plating standard. Black bars: }}$ average ratio in triplicate samples (whether frozen or liquid); open bars: average ratio in liquid samples only; grey bars: in frozen samples only. Error bars are \pm SE of the mean of triplicate samples (black bars) or range of 2 samples. At $t=0$, error bar is too small to be visible. (B) Changes in the concentration of bacteria $(\boldsymbol{\Delta})$ or viruses $(\Delta)$ monitored by epifluorescence microscopy in liquid samples at -12 to $-13^{\circ} \mathrm{C}$. Error bars represent \pm SE of the mean of the microscopic count

\section{Phage production under hydrostatic pressure}

In the absence of 9A, after a $24 \mathrm{~h}$ incubation period under pressures of 10 to $200 \mathrm{~atm}$, bacterial concentrations increased modestly (10 to $60 \%$ ) at 10 and $100 \mathrm{~atm}$ and doubled at $200 \mathrm{~atm}$. In contrast, viral concentrations increased 4 -fold at $10 \mathrm{~atm}$ and marginally (15 to $20 \%$ ) at 100 and $200 \mathrm{~atm}$. At the highest pressures of 
Table 4. Concentrations of bacteria and phages determined microscopically after incubation at $-1^{\circ} \mathrm{C}$ and a range of hydrostatic pressures. Phage $\mathrm{f}_{\mathrm{f}} / \mathrm{Phage}_{\mathrm{i}}$ : final concentration of phages at the end of the incubation period divided by initial phage concentration. Initial concentrations were $9.3 \times 10^{6}$ bacteria ml $^{-1}$ and $2.7 \times 10^{7}$ phage $\mathrm{ml}^{-1}$

\begin{tabular}{|c|c|c|c|c|c|}
\hline $\begin{array}{l}\text { Pressure } \\
\text { (atm) }\end{array}$ & $\begin{array}{l}\text { Incubation } \\
\operatorname{period}^{\text {a }}(d)\end{array}$ & $\begin{array}{r}34 \mathrm{H}(\mathrm{ce} \\
\text { No-phage cont }\end{array}$ & $\begin{array}{l}\mathrm{ml}^{-1} \text { ) } \\
\text { Phage added }\end{array}$ & $\begin{array}{c}\text { 9A } \\
\left(\text { phage } \mathrm{ml}^{-1} \text { ) }\right.\end{array}$ & $\begin{array}{l}\text { Phage }_{\mathrm{f}} / \\
\text { Phage }_{i}\end{array}$ \\
\hline 1 & 3 & $2.0 \times 10^{8}$ & $7.7 \times 10^{6}$ & $1.2 \times 10^{10}$ & 440 \\
\hline 10 & 3 & $2.6 \times 10^{7}$ & $1.3 \times 10^{6}$ & $1.9 \times 10^{10}$ & 700 \\
\hline 100 & 7 & $2.7 \times 10^{7}$ & $6.3 \times 10^{6}$ & $1.5 \times 10^{10}$ & 560 \\
\hline 200 & 7 & $8.8 \times 10^{6 a}$ & $3.9 \times 10^{6}$ & $1.9 \times 10^{8}$ & 7 \\
\hline 400 & 14 & $3.8 \times 10^{5 b}$ & $3.5 \times 10^{6}$ & $1.4 \times 10^{7}$ & 0.5 \\
\hline 600 & 14 & $4.2 \times 10^{6}$ & $3.2 \times 10^{6}$ & $1.6 \times 10^{7}$ & 0.6 \\
\hline
\end{tabular}

ene glycol 8000 (as in Sillankorva et al. 2004b) did not improve adsorption or increase EOP (data not shown).

\section{One-step growth curves}

The absence of a meaningful measure of adsorption rate necessitated plating multiple growth tubes for onestep growth curves, since the number of cells infected over the $10 \mathrm{~min}$ adsorption period could not be calculated a priori. Longer adsorption periods were undesirable to the extent that infections would not be synchronous. The fraction of viruses that infected cells was determined after the
400 and 600 atm, concentrations of both viruses and bacteria were reduced by about 25 and $50 \%$, respectively, with noticeably deformed cells at $600 \mathrm{~atm}$.

Over the full incubation periods of 3,7 or $14 \mathrm{~d}$, viral concentrations increased 440- to 700 -fold at 1, 10 and $100 \mathrm{~atm}$, more modestly at $200 \mathrm{~atm}$ (by a factor of 7; Table 4), and declined by half at higher pressures. In the absence of viruses, 2- to 22-fold increases in bacterial concentration demonstrated that $34 \mathrm{H}$ grew at pressures between 1 and 200 atm (Table 4). No evidence for growth was seen at 400 or $600 \mathrm{~atm}$; the bacteria were visibly deformed at both pressures. Consistent with phage-induced mortality, bacterial concentrations were 2.3 to 26 times lower when phages were present than absent at pressures between 1 and 200 atm. Because of genomic evidence that $34 \mathrm{H}$ may be a lysogen (Methé et al. 2005, Wells 2006), we also examined the negative controls for evidence of lysogenic induction by pressure, but no phage were detected microscopically.

\section{Adsorption experiments}

Eighteen attempts were made to measure adsorption of $9 \mathrm{~A}$ to $34 \mathrm{H}$, varying the MOI, the growth temperature of $34 \mathrm{H}$ prior to infection, the adsorption temperature and the assay period. All experiments yielded results qualitatively similar to those shown in Fig. 4, whether using SYBR or PFU counts to determine the phage concentration and despite the difference in centrifugation conditions for the 2 methods. Although over a 2-h period concentrations of unadsorbed phage tended to decline, the decline was relatively small and could not be measured with precision. No marked difference was detected between adsorption at -1 or $8^{\circ} \mathrm{C}$. Further purification of 9A by precipitation in polyethylfact, however, and in both the -1 and $8{ }^{\circ} \mathrm{C}$ experiments, was very low: $\sim 0.07$ and $\sim 0.006 \%$, respectively. The calculated fraction for $-1{ }^{\circ} \mathrm{C}$ is probably an overestimate, however, since phage concentration in the stock solution used for that experiment was measured only in terms of PFU; concentrations determined by SYBR staining were typically 10 to 100 times greater (as discussed with respect to EOP).

At $-1^{\circ} \mathrm{C}$, the $9 \mathrm{~A}-34 \mathrm{H}$ PHS had a latent period of 4 to $5 \mathrm{~h}$, a prolonged rise time of 4 to $5 \mathrm{~h}$ and an average burst size of $\sim 55$ viruses (Fig. 5). In comparison, the latent period, rise time and average burst size at $8^{\circ} \mathrm{C}$ were reduced, to $2.5-3 \mathrm{~h}, 2-2.5 \mathrm{~h}$ and $\sim 5$ viruses, respectively (Fig. 5).

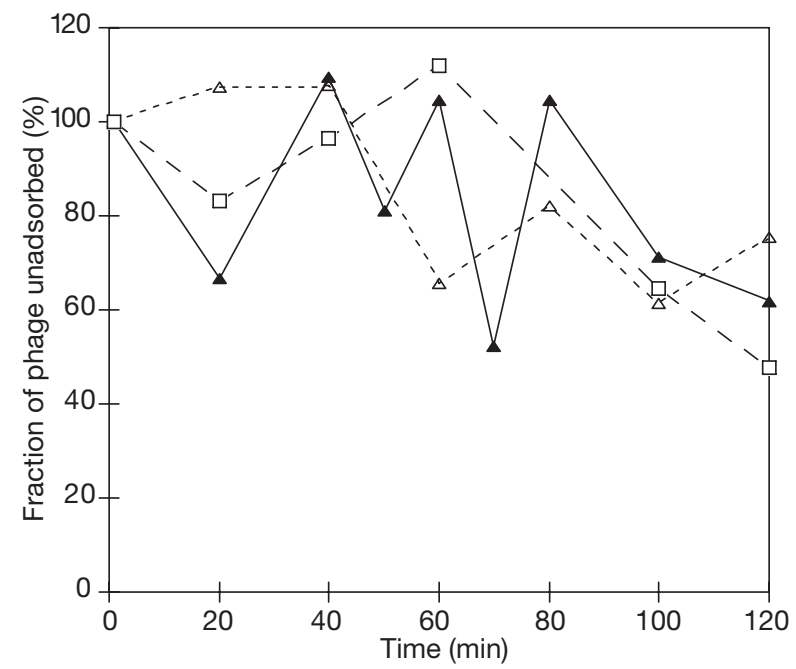

Fig. 4. Phage 9A. Adsorption to host Colwellia psychrerythraea Strain $34 \mathrm{H}$ at an MOI of $\sim 0.1$ in 3 independent experiments as determined from PFU $(\boldsymbol{\Delta})$ or SYBR-staining $(\triangle)$ at $-1^{\circ} \mathrm{C}$, or by SYBR-staining at $8^{\circ} \mathrm{C}(\square)$. Bacteria were grown at $2^{\circ} \mathrm{C}$ (or $8^{\circ} \mathrm{C}$ ) prior to infection for the $-1^{\circ} \mathrm{C}$ (or $8^{\circ} \mathrm{C}$ ) experiments 


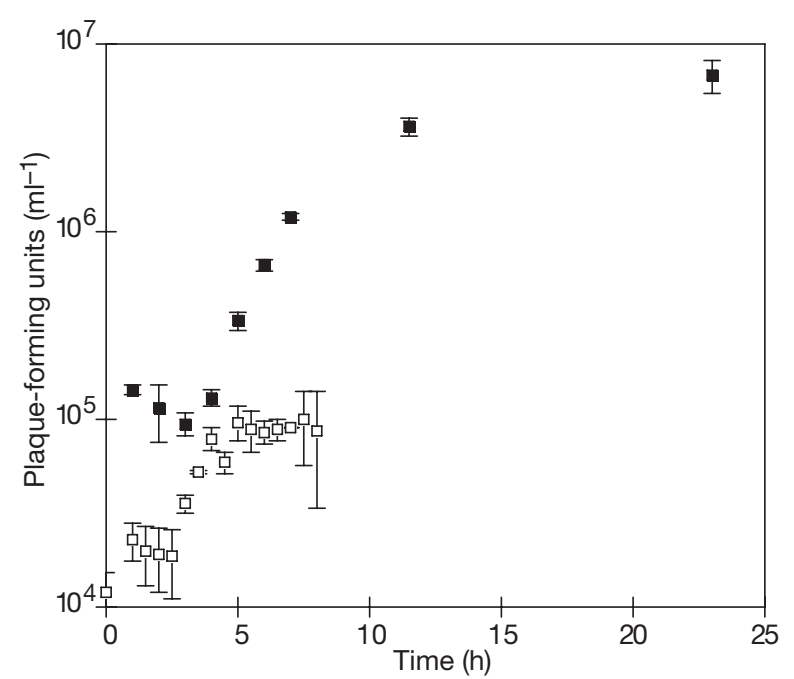

Fig. 5. Phage 9A. One-step growth curves for phage grown on Colwellia psychrerythraea $34 \mathrm{H}$ at $-1^{\circ} \mathrm{C}(\square)$ or $8^{\circ} \mathrm{C}(\square)$. Error bars represent $\pm \mathrm{SE}$ of the mean of redundant measurements (defined in 'Materials and methods')

\section{DISCUSSION}

Phage 9A, with a double-stranded DNA genome, Bacterial host and non-contractile tail, can be classified according to the 'Seventh Report of the International Committee on Taxonomy of Viruses' (van Regenmortel et al. 2000) as a Siphoviridae. The estimated capsid size and 80 to $90 \mathrm{~kb}$ genome are most similar to T5-like viruses, but no tail fibers were observed.

Under the conditions tested, 9A had 2 closely related hosts, Colwellia psychrerythraea $34 \mathrm{H}$ from the Arctic and C. demingiae ACAM $459^{\mathrm{T}}$ from the Antarctic, thus qualifying, like many marine Siphoviridae, as a virus with a broad host range according to the criteria of Wichels et al. (2002). Conclusions reached about host range, however, depend critically on experimental conditions and type of assay. In our case, prior host starvation, temperature and salinity all affected the propensity of $9 \mathrm{~A}$ to form plaques, with the 2 identified hosts having overlapping but distinct characteristics (Tables 2 \& 3). Phage production also persisted under conditions not conducive to plaque formation $\left(8^{\circ} \mathrm{C} ; \mathrm{cf}\right.$. Table 2 with Fig. 5), as observed in other PHS (Adams 1959). An important ecological implication of these data is the suggestion of a mechanism by which high concentrations of bacteria and phage can coexist: host specificity may reflect adjustable bacterial phenotypes responsive to changing environmental conditions. These findings also provide a reminder that no current assay for host specificity is ecologically satisfying, being undertaken against a minuscule representation of microbial diversity and always under set environmental conditions.
The temperature range of plaque formation by $9 \mathrm{~A}$ accords with our definition of a cold-active virus: on both hosts, plaques were observed at $\leq 4^{\circ} \mathrm{C}$ and down to $-6^{\circ} \mathrm{C}$ (below which plates froze). The latter data add to the report by Delisle \& Levin (1972b) of plaque formation by Pseudomonas putrefaciens down to $-5^{\circ} \mathrm{C}$, to our knowledge the only other phage study to test subzero temperatures. We also found evidence by both plaque assay and epifluorescence microscopy that $34 \mathrm{H}$ continued to produce phage in liquid samples at temperatures between -10 and $-13^{\circ} \mathrm{C}$ (Fig. 3), consistent with the theoretical minimum growth temperature of $34 \mathrm{H}\left(-14.5^{\circ} \mathrm{C}\right.$; Huston 2003$)$, prior observations that $34 \mathrm{H}$ remains motile at $-10^{\circ} \mathrm{C}$ (Junge et al. 2003) and the current, minimum growth temperature of a bacterium in pure culture $\left(-12^{\circ} \mathrm{C}\right.$ for Psychromonas ingrahamii; Breezee et al. 2004). In fact, the observed increase in $34 \mathrm{H}$ concentrations after the first $11 \mathrm{~d}$ at temperatures between -12 and $-13^{\circ} \mathrm{C}$ implies a generation time of 5 to $7 \mathrm{~d}$ (Fig. 3B) compared to $\sim 10 \mathrm{~d}$ for $P$. ingrahamii at $-12^{\circ} \mathrm{C}$. These results parallel experimental evidence from winter sea-ice brines for bacterial metabolic activity at -2 to $-20^{\circ} \mathrm{C}$ (Junge et al. 2004) and viral production and bacterial growth at $-12^{\circ} \mathrm{C}$ (Wells \& Deming 2006a). Significant production of 9A at $-10^{\circ} \mathrm{C}$ was not observed (by PFU assay) in frozen samples, possibly due to impingement of host cells by ice crystals or to high salinities in liquid brine inclusions where cells and viruses presumably partitioned. Salt inhibition is supported by the failure to detect viral production at salinities $>50$ psu on either host (albeit at $-1^{\circ} \mathrm{C}$; Table 3$)$. The possibility exists that phage were produced in frozen samples but were defective. Inactivation after production is unlikely, since only relatively small (16 to $34 \%$ ) decreases in 9A infectivity or viral concentration were observed over 1 mo at $-12^{\circ} \mathrm{C}$ in brine of $160 \mathrm{psu}$ (Wells \& Deming 2006c). Moreover, normalized phage concentrations in frozen samples did not decline appreciably from initial values (Fig. 3A).

Like other cold-active phages, 9A when grown on host $34 \mathrm{H}$ appears to have a more restricted temperature range than does the host itself, not forming plaques above $4^{\circ} \mathrm{C}\left(8^{\circ} \mathrm{C}\right.$ if $34 \mathrm{H}$ is first starved $)$ and not producing viruses at $13^{\circ} \mathrm{C}$ (Table 2 ; insufficient data are available for a similar analysis of 9A on Colwellia demingiae). Restricted temperature ranges may suggest a general feature of cold-active phage: adaptations to low thermal energy may be offset by higher temperatures seldom if ever experienced in situ. This possibility, the greater number of PFU observed using silica-gel rather than agar overlays, and the extreme thermolability of 9A (as well as other cold-active viruses; see Wells \& Deming 2006c), argue for the importance of acquiring and studying phage-host 
dynamics under experimental conditions mimicking as closely as possible those of interest environmentally.

A large fraction of the cold waters of the ocean are under significant pressure; i.e. $\sim 75 \%$ of the ocean by volume lies below a depth of $1 \mathrm{~km}$ (calculated from Table J.6 in Pilson 1998; only $\sim 5 \%$ is at or above $200 \mathrm{~m}$ ). The presence in the deep ocean of high concentrations of viruses (e.g. $10^{4}$ to $10^{8} \mathrm{ml}^{-1}$; Hara et al. 1996, Weinbauer et al. 2003, Wommack et al. 2004, Ortmann \& Suttle 2005) hints at a significant viral role in bacterial mortality there (Weinbauer et al. 2003). Yet, to our knowledge, apart from the work of Wiebe \& Liston (1968) on a PHS functional at 200 atm (temperature unspecified), no laboratory-based studies of phage production under relevant hydrostatic pressures are available. In our work, $34 \mathrm{H}$ produced phage under pressures of at least $200 \mathrm{~atm}$ at $-1^{\circ} \mathrm{C}$ (Table 4), simulating conditions on Arctic continental shelves. The 440to 700 -fold increase in viral concentration observed at low pressures of 1 to $100 \mathrm{~atm}$ implies that several infection cycles occurred. In contrast, the modest ( 7 -fold) increase at $200 \mathrm{~atm}$, most of it happening after the first day at pressure, may indicate that only a single infection cycle took place, whether because viruses could not infect cells under these conditions, or cell growth had diminished or ceased, or the incubation period ( 7 d) was too short. Deeper waters and sediments may yield PHS with greater tolerance of, or adaptation to, high pressures.

Under our experimental conditions, the 9A-34H PHS is notable for its low EOP and the absence of measurable phage adsorption. Low EOP may in part reflect the use of epifluorescence microscopy to determine total phage concentrations, since EOPs are normally standardized to more conservative, electron microscopic counts. Epifluorescent counts of viruses typically correlate with electron microscopic counts, however, even if generally being higher (e.g. Noble \& Fuhrman 1998). Slow adsorption may also help to explain the low EOP, if only a small fraction of cells were infected prior to plating. The essentially undetectable adsorption is unlikely to be a methodological artifact, since it was supported by several different types of measurements, including assay of unadsorbed phage by both plating and microscopy (Fig. 4) and of adsorbed phage in the one-step growth experiments $(<0.1 \%$ of phage adsorbed within $10 \mathrm{~min})$, and the first experiment conducted between -10 and $-12^{\circ} \mathrm{C}(<1 \%$ adsorbed $)$. These results instead suggest 3 possible explanations.

First, only a small fraction of cells might be susceptible to phage 9A. This possibility can be excluded, since eventually 9A routinely lysed $>95 \%$ of bacteria under permissive conditions (data not shown). Second, the vast majority of the viruses might not be infective. Yet, under some circumstances, the majority of viruses were infective, with the highest measured EOP being $74 \%$. Third (and most likely), a changeable cellular phenotype might account for the low adsorption rate. This explanation is consistent with the results in Fig. 2, which imply that the substantial drop in EOP could be due to a systematic bacterial adjustment. Note that Fig. 2 cannot be interpreted as selection of phage-resistant mutants, since the bacteria and phage were not cultured together. The importance of host phenotypic changes to phage dynamics is also implied by the extension of the temperature range of plaque formation following starvation and by the decrease in number of plaques commonly observed at different temperatures if $34 \mathrm{H}$ was first grown at $8^{\circ} \mathrm{C}$ rather than $-1^{\circ} \mathrm{C}$. Phenotypic variability within the bacterial population could also account for the long rise times. In the context of lysogeny and pseudolysogeny, other studies have implicated modified availability of phage receptors on the cell surface to explain similar results (Barksdale \& Arden 1974, Williamson et al. 2001). While such modification is often interpreted in terms of genotypic changes, either through the selection of resistant 'adhesion-deficient' mutants or phage conversion (Williamson et al. 2001), phenotypic changes associated with the physiological state of the host (Delbrück 1940) or with cell-surface characteristics, including those responsive to temperature (Benedi et al. 1991), are also known to affect adsorption. These latter features could include the rare or transient expression of a receptor, removal of a receptor or receptor masking (Benedi et al. 1991), or release of competitive binding agents by the host (the suggested Factor X of Moebus 1997a,b, although Moebus believed that Factor X was probably phage-encoded). We considered the possibility that $34 \mathrm{H}$ was susceptible to infection only during a particular stage of its growth cycle but did not succeed in synchronizing growth. Were the hypothesis true, one would expect to observe a relationship between EOP and the frequency or number of dividing cells, which we did not (Fig. 2).

With the exception of 3 non-marine PHS examined at 3.5 to $4^{\circ} \mathrm{C}$ (Olsen et al. 1968, Kulpa \& Olsen 1971, Sillankorva et al. 2004a), the $9 \mathrm{~A}-34 \mathrm{H}$ system at $-1{ }^{\circ} \mathrm{C}$ has a shorter latent period ( 4 to $5 \mathrm{~h}$ ) and larger burst size (55) than the other known cold-active PHS at similarly low temperatures. As reported for several cold-active PHS (Olsen et al. 1968, Kulpa \& Olsen 1971, Whitman \& Marshall 1971b, Sillankorva et al. 2004a), the latent period was shorter ( 2.5 to $3 \mathrm{~h}$ ) at a warmer temperature $\left(8^{\circ} \mathrm{C}\right)$, although Sillankorva et al. (2004a) found that this effect depended on the temperature of cell growth before infection. In contrast to these studies, however, an increased burst size was not observed at $8^{\circ} \mathrm{C}$, instead being 1 order of magnitude smaller than that measured at $-1^{\circ} \mathrm{C}$ (Fig. 5). Likewise, the phage production rate, defined as the burst size divided by the latent 
period (following Zachary 1976), was also an order of magnitude higher at $-1^{\circ} \mathrm{C}$ (and a factor of 5 higher if the rise times were included with the latent period). If considered in the context of genome replication, the release at $-1^{\circ} \mathrm{C}$ of 55 viruses per infected cell, each with an 80 to $90 \mathrm{~kb}$ genome, is equivalent to the replication of a 4.4 to $5.0 \mathrm{Mb}$ genome, comparable in size to that of $34 \mathrm{H}(5.4 \mathrm{Mb}$; Methé et al. 2005) but requiring only 0.1 to 0.2 of the generation time of $34 \mathrm{H}$ at $-1^{\circ} \mathrm{C}$ to be produced. In contrast, at $8^{\circ} \mathrm{C}$ the infection cycle lasted 0.2 to 0.3 of the $34 \mathrm{H}$ generation time, but only $\sim 0.5 \mathrm{Mb}$ of phage genomes were made. These results may imply an extremely cold-active, phageencoded enzyme, such as a DNA polymerase. They also emphasize that optimum conditions for phage production do not necessarily correspond to those for bacterial growth.

Besides the well-resolved one-step growth curves at -1 and $8^{\circ} \mathrm{C}$, the consistency of normalized phage concentrations in unfrozen samples after 0 and $5 \mathrm{~d}$, and again after 10 and $15 \mathrm{~d}$, allows an estimation of the latent period and burst size at -12 to $-10^{\circ} \mathrm{C}$ as 5 to $10 \mathrm{~d}$ and 5 viruses, respectively (Fig. 3A). At the slightly colder $\left(-13\right.$ to $\left.-12^{\circ} \mathrm{C}\right)$ temperatures of the second experiment, the microscopically-observed stepwise increase in viral concentrations approximately $2 \mathrm{wk}$ apart (Fig. 3B) is reminiscent of a synchronized infection (although no effort was made to synchronize infection in this experiment) with a latent period of $<14 \mathrm{~d}$. This apparent synchronization may again reflect phenotypic plasticity. The lengthening of the latent period and reduction of the burst size relative to $-1^{\circ} \mathrm{C}$ are more in line with the observations of prior investigators and perhaps better understood as a response to temperature stress rather than temperature per se. We note also that measurements below $-10^{\circ} \mathrm{C}$ may be biased by prior growth of the cells at $-1^{\circ} \mathrm{C}$ (rather than $-10^{\circ} \mathrm{C}$ ) for the reasons already discussed, although the stepwise increase in viruses shown in Fig. 3B implies that at least some infections occurred once cells had acclimated to the experimental temperature.

The one-step growth curves at -1 and $8^{\circ} \mathrm{C}$ have in common long rise times comparable in length to the latent period. Asynchronous infection is unlikely to account for this observation, since the adsorption period was only $10 \mathrm{~min}$, after which the phages were removed and cells washed. Since rise times are frequently not reported, the prevalence of this feature among marine PHS is not clear, although rise times comparable to latent periods are apparent in some PHS studied by Proctor et al. (1993) and Suttle \& Chan (1993). In terms of TEM estimates of virus-induced mortality, long rise times may be important in estimating the fraction of the latent period when virus-like particles are visible; in particular, some inconsistency appears in how or whether rise times and latent periods are distinguished (Proctor et al. 1993).

Finally, at both -1 and $8{ }^{\circ} \mathrm{C}$, the latent period of the 9A-34H system was considerably shorter than the corresponding doubling time of the bacterium under the relevant conditions $\left(>48 \mathrm{~h}\right.$ at $-1{ }^{\circ} \mathrm{C}$ and $>17 \mathrm{~h}$ at $8^{\circ} \mathrm{C}$; Huston 2003 and present Fig. 2). Contrary to the common assumption of equality, the ratio of the latent period to the generation time $(\gamma)$ was thus only 0.1 to 0.2 (at $-1^{\circ} \mathrm{C}$ ) and 0.2 to 0.3 (at $8^{\circ} \mathrm{C}$ ), depending on whether or not the rise time was added to the latent period. If this feature $(\gamma<1)$ is common to other marine or cold-active phages and their hosts, models must account for it or risk a substantial underestimation of the importance of viral processes in the ocean. In particular, Binder (1999) showed that TEM estimates of virusinduced mortality are very sensitive to the assumed value of $\gamma$ : for example, relative to the common assumption that $\gamma=1$, if the true value of $\gamma$ is 0.5 and the average frequency of visibly infected cells is $2 \%$, then mortality due to viruses will be underestimated by approximately half (see Fig. 6 in Binder 1999).

\section{CONCLUSIONS}

Besides its unprecedented cold activity, Phage 9A exhibits different traits on its 2 identified hosts, which can reflect host history (for example, prior starvation) as well as immediate circumstances. Much of the work with cold-active phages, and marine PHS more generally, has not been attentive to these possibilities. In addition to making such work difficult to interpret, oversights of this nature may blind us to important nuances of phage ecology. For example, the different temperature and salinity ranges of plaque formation by 9A on Colwellia psychrerythraea $34 \mathrm{H}$ and $C$. demingiae ACAM $459^{\mathrm{T}}$ (as well as the effect of prior starvation on the temperature range on $34 \mathrm{H}$ ) hint at 'niche partitioning' of hosts in the ocean; i.e. at the vulnerability of different hosts to a given phage varying with environmental conditions, possibly relevant to genetic exchange and viral traffic between biomes (Sano et al. 2004). These and other documented characteristics of the $9 \mathrm{~A}-34 \mathrm{H}$ system, including the change in EOP with culture age and the undetectable adsorption rate, imply phenotypic plasticity rather than mutational changes. The results of this study thus direct attention specifically to the impact of viruses on microbial mortality and diversity in the cold ocean but, more generally, to viral interactions with and influences on cellular phenotypes, such as surface-associated receptors, polymeric substances and released enzymes, affecting both the ability of the virus to infect its host(s) and the biogeochemical role of the host. 
Acknowledgements. We thank M. Borriss, J. Bowman, K. Junge, J. Kaye, T. Schweder, J. Staley and B. van Mooy for bacterial strains, M. Middelboe for advice early in this project, J. Baross for discussion, S. Carpenter for laboratory assistance, and R. Sirius, S. Redding and D. Moore. This work is a contribution to the international Canadian Arctic Shelf Exchange Study (CASES) and was funded by the UW Astrobiology Program through NSF-IGERT (DGE-9870713) and NASA-ABI (NCC 2-1273) awards.

\section{LITERATURE CITED}

Ackermann HW, DuBow MS (1987) Viruses of prokaryotes, Vol I: General properties of bacteriophages. CRC Press, Boca Raton, FL

Adams MH (1959) Bacteriophages. Interscience, New York

Barksdale L, Arden SB (1974) Persisting bacteriophage infections, lysogeny and phage conversions. Annu Rev Microbiol 28:265-300

Benedi VJ, Regue M, Alberti S, Camprubi S, Tomas JM (1991) Influence of environmental conditions on infection of Klebsiella pneumoniae by two different types of bacteriophages. Can J Microbiol 37:270-275

Bergh O, Borsheim KY, Bratbak G, Heldal M (1989) High abundance of viruses found in aquatic environments. Nature 340:467-468

Binder B (1999) Reconsidering the relationship between virally induced bacterial mortality and frequency of infected cells. Aquat Microb Ecol 18:207-215

Borriss M, Helmke E, Hanschke R, Schweder T (2003) Isolation and characterization of marine psychrophilic phage-host systems from Arctic sea ice. Extremophiles 7:377-384

Bowman JP, McCuaig RD (2003) Biodiversity, community structural shifts and biogeography of prokaryotes within Antarctic continental shelf sediment. Appl Environ Microbiol 69:2463-2483

Bowman JP, Gosink JJ, McCammon SA, Lewis TE and 5 others (1998) Colwellia demingiae sp. nov., Colwellia hornerae sp. nov., Colwellia rossensis sp. nov. and Colwellia psychrotropica sp. nov.: psychrophilic Antarctic species with the ability to synthesize docosahexaenoic

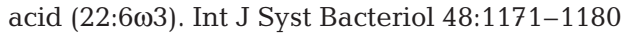

Breezee J, Cady N, Staley JT (2004) Subfreezing growth of the sea ice bacterium Psychromonas ingrahamii. Microb Ecol 47:300-304

Brinkmeyer R, Knittel K, Jurgens J, Weyland H, Amann R, Helmke E (2003) Diversity and structure of bacterial communites in Arctic versus Antarctic pack ice. Appl Environ Microbiol 69:6610-6619

Chen F, Lu J, Binder BJ, Liu Y, Hodson RE (2001) Application of digital image analysis and flow cytometry to enumerate marine viruses stained with SYBR Gold. Appl Environ Microbiol 67:539-545

D'Aoust JY, Kushner DJ (1972) Vibrio psychrerythraeus sp. n.: classification of the psychrophilic marine bacterium NRC 1004. J Bacteriol 111:340-342

Delbrück M (1940) Adsorption of bacteriophage under various physiological conditions of the host. J Gen Physiol 23:631-642

Delisle AL, Levin RE (1969) Bacteriophages of psychrophilic pseudomonads. II. Host range of phage active against Pseudomonas putrefaciens. Antonie Leeuwenhoek 35: 318-324

Delisle AL, Levin RE (1972a) Characteristics of three phages infectious for psychrophilic fishery isolates of Pseudomonas putrefaciens. Antonie Leeuwenhoek 38:1-8
Delisle AL, Levin RE (1972b) Effect of temperature on an obligately psychrophilic phage-host system of Pseudomonas putrefaciens. Antonie Leeuwenhoek 38:9-15

DeLong EF, Franks DG, Yayanos AA (1993) Phylogenetic diversity of aggregate-attached vs. free-living marine bacterial assemblages. Limnol Oceanogr 38:924-934

Deming JW (2001) Unusual or extreme high-pressure marine environments. In: Hurst CJ, Knudsen GR, McInerney MJ, Stetzenbach LD, Walter MV (eds) ASM manual of environmental microbiology. ASM Press, Washington, DC, p 478-490

Dietz AS, Yayanos AA (1978) Silica gel media for isolating and studying bacteria under hydrostatic pressure. Appl Environ Microbiol 36:966-968

Eilers H, Pernthaler J, Glockner FO, Amann R (2000) Culturability and in situ abundance of pelagic bacteria from the North Sea. Appl Environ Microbiol 66:3044-3051

Elder AL, Tanner FW (1928) Action of bacteriophage on psychrophilic organisms. J Infect Dis 43:403-406

Gillan DC, Speksnijder AGCL, Zwart G, De Ridder C (1998) Genetic diversity of the biofilm covering Montacuta ferruginosa (Mollusca, Bivalvia) as evaluated by denaturing gradient gel electrophoresis analysis and cloning of PCRamplified gene fragments coding for 16S rRNA. Appl Environ Microbiol 64:3464-3472

Greer GG (1982) Psychrotrophic bacteriophages for beef spoilage pseudomonads. J Food Prot 45: 1318-1325

Greer GG (1983) Psychrotrophic Brocothrix thermosphacta bacteriophages isolated from beef. Appl Environ Microbiol 46:245-251

Guixa-Boixereu N, Vaque D, Gasol JM, Sanchez-Camara J, Pedros-Alio C (2002) Viral distribution and activity in Antarctic waters. Deep-Sea Res II 49:827-845

Hara S, Koike I, Terauchi K, Kamiya H, Tanoue E (1996) Abundance of viruses in deep oceanic waters. Mar Ecol Prog Ser 145:269-277

Huston AL (2003) Bacterial adaptation to the cold: in situ activities of extracellular enzymes in the North Water polynya and characterization of a cold-active aminopeptidase from Colwellia psychrerythraea strain $34 \mathrm{H}$. PhD dissertation, University of Washington, Seattle, WA

Jensen EC, Schrader HS, Rieland B, Thompson TL, Lee KW, Nickerson KW, Kokjohn TA (1998) Prevalence of broadhost-range lytic bacteriophages of Spaerotilus natans, Escherichia coli, and Pseudomonas aeruginosa. Appl Environ Microbiol 64:575-580

Junge K, Krembs C, Deming J, Stierle A, Eicken H (2001) A microscopic approach to investigate bacteria under in situ conditions in sea-ice samples. Ann Glaciol 33: 304-310

Junge K, Imhoff F, Staley JT, Deming JW (2002) Phylogenetic diversity of numerically important Arctic sea-ice bacteria cultured at subzero temperature. Microb Ecol 43:315-328

Junge K, Eicken H, Deming JW (2003) Motility of Colwellia psychrerythraea Strain $34 \mathrm{H}$ at subzero temperatures. Appl Environ Microbiol 69:4282-4284

Junge $\mathrm{K}$, Eicken H, Deming JW (2004) Bacterial activity at -2 to $-20^{\circ} \mathrm{C}$ in Arctic wintertime sea ice. Appl Environ Microbiol 70:550-557

Kulpa CF, Olsen RH (1971) Properties of psychrophilic bacteriophage specific for Micromonas cryophilus. Can J Microbiol 17:157-160

Methé, BA, Nelson KE, Deming JW, Momen B and 23 others (2005) The psychrophilic lifestyle as revealed by the genome sequence of Colwellia psychreyrthraea $34 \mathrm{H}$ through genomic and proteomic analysis. Proc Natl Acad Sci USA 102:10913-10918 
Middelboe M, Nielsen TG, Bjørnsen PK (2002) Virus and bacterial production in the North Water: in situ measurements, batch-culture experiments and characterization and distribution of a virus-host system. Deep-Sea Res II 49:5063-5079

Moebus K (1997a) Investigations of the marine lysogenic bacterium H24. I. General description of the phage-host system. Mar Ecol Prog Ser 148:217-228

Moebus K (1997b) Investigations of the marine lysogenic bacterium H24. II. Development of pseudolysogeny in nutrient-rich broth culture. Mar Ecol Prog Ser 148:229-240

Noble RT, Fuhrman JA (1998) Use of SYBR Green I for rapid epifluorescence counts of marine viruses and bacteria. Aquat Microb Ecol 14:113-118

Olsen RH (1967) Isolation and growth of psychrophilic bacteriophage. Appl Microbiol 15:198

Olsen RH, Metcalf ES, Todd JK (1968) Characteristics of bacteriophages attacking psychrophilic and mesophilic pseudomonads. J Virol 2:357-364

Ortmann AC, Suttle CA (2005) High abundances of viruses in a deep-sea hydrothermal vent system indicates viral mediated microbial mortality. Deep-Sea Res I 52:1515-1527

Patel TR, Jackman DM (1986) Susceptibility of psychrotrophic pseudomonads of milk origin to psychrotrophic bacteriophages. Appl Environ Microbiol 51:446-448

Pilson MEQ (1998) An introduction to the chemistry of the sea. Prentice-Hall, Upper Saddle River, NJ

Proctor LM, Okubo A, Fuhrman JA (1993) Calibrating estimates of phage-induced mortality in marine bacteria: ultrastructural studies of marine bacteriophage development from one-step growth experiments. Microb Ecol 25:161-182

Sano E, Carlson S, Wegley L, Rohwer F (2004) Movement of viruses between biomes. Appl Environ Microbiol 70: 5842-5846

Sillankorva S, Oliveira R, Vieira MJ, Sutherland I, Azeredo J (2004a) Pseudomonas fluorescens infection by bacteriophage fS1: the influence of temperature, host growth phase and media. FEMS Microbiol Lett 241:13-20

Sillankorva S, Oliveira R, Vieira MJ, Sutherland I, Azeredo J (2004b) Bacteriophage $\phi S 1$ infection of Pseudomonas fluorescens planktonic cells versus biofilms. Biofouling 20: $133-138$

Spencer R (1955) A marine bacteriophage. Nature 175: 690-691

Spencer R (1960) Indigenous marine bacteriophages. J Bacteriol 79:614

Spencer R (1963) Bacterial viruses in the sea. In: Oppenheimer $\mathrm{CH}$ (ed) Symposium on marine microbiology. Charles C. Thomas, Springfield, IL, p 350-365

Stamatin N (1963) Les témperatures d'inactivation et de multiplication des phages Cereus-Anthracis-Mycoides. Ann Institut Pasteur (Paris) 105:515-523

Steward GF, Smith DC, Azam F (1996) Abundance and distribution of bacteria and viruses in the Bering and Chukchi Seas. Mar Ecol Prog Ser 131:287-300

Editorial responsibility: Jed Fuhrman,

Los Angeles, California, USA
Suttle CA, Chan AM (1993) Marine cyanophages infecting oceanic and coastal strains of Synechococcus: abundance, morphology, cross-infectivity and growth characteristics. Mar Ecol Prog Ser 92:99-109

Torrella F, Morita RY (1979) Evidence by electron micrographs for a high incidence of bacteriophage particles in the waters of Yaquina Bay, Oregon: ecological and taxonomical implications. Appl Environ Microbiol 37:774-778

van Regenmortel MHV, Fauquet CM, Bishop DHL, Carstens EB and 7 others (eds) (2000) Virus taxonomy: Seventh report of the international committee on taxonomy of viruses. Academic Press, San Diego, CA

Weinbauer MG, Brettar I, Hofle MG (2003) Lysogeny and virus-induced mortality of bacterioplankton in surface, deep, and anoxic marine waters. Limnol Oceanogr 48: $1457-1465$

Wells LE (2006) Viral adaptations to life in the cold. PhD dissertation, University of Washington, Seattle, WA

Wells LE, Deming JW (2006a) Modelled and measured dynamics of viruses in Arctic winter sea-ice brines. Environ Microbiol 8:1115-1121

Wells LE, Deming JW (2006b) Significance of bacterivory and viral lysis in bottom waters of Franklin Bay, Canadian Arctic, during winter. Aquat Microb Ecol 43:209-221

Wells LE, Deming JW (2006c) Effects of temperature, salinity and clay particles on inactivation and decay of coldactive marine Bacteriophage 9A. Aquat Microb Ecol 45:31-39

Wells LE, Cordray M, Bowerman S, Miller LA, Vincent WF, Deming JW (2006) Archaea in particle-rich waters of the Beaufort Shelf and Franklin Bay, Canadian Arctic: clues to an allochthonous origin? Limnol Oceanogr 51: 47-59

Whitman PA, Marshall RT (1971a) Isolation of psychrophilic bacteriophage-host systems from refrigerated food products. Appl Microbiol 22:220-223

Whitman PA, Marshall RT (1971b) Characterization of two psychrophilic Pseudomonas bacteriophages isolated from ground beef. Appl Microbiol 22:463-468

Wichels A, Gerdts G, Schütt C (2002) Pseudoalteromonas spp. phages, a significant group of marine bacteriophages in the North Sea. Aquat Microb Ecol 27:233-239

Wiebe WJ, Liston J (1968) Isolation and characterization of a marine bacteriophage. Mar Biol 1:244-249

Williamson SJ, McLaughlin MR, Paul JH (2001) Interaction of the $\phi$ HSIC virus with its host: lysogeny of pseudolysogeny? Appl Environ Microbiol 67:1682-1688

Wommack KE, Williamson SJ, Sundbergh A, Helton RR, Glazer BT, Portune K, Cary SC (2004) An instrument for collecting discrete large-volume water samples suitable for ecological studies of microorganisms. Deep-Sea Res I 51:1781-1792

Zachary A (1976) Physiology and ecology of bacteriophages of the marine bacterium Beneckea natriegens: salinity. Appl Environ Microbiol 31:415-422

Submitted: December 21, 2005; Accepted: July 20, 2006

Proofs received from author(s): October 23, 2006 